\title{
P357: A descriptive study of maternal deaths in Algeria in 2011
}

\author{
N Keddad \\ From 2nd International Conference on Prevention and Infection Control (ICPIC 2013) \\ Geneva, Switzerland. 25-28 June 2013
}

\section{Introduction}

In our country, despite a substantial increase in the assisted delivery rate to $97 \%$, the maternal mortality rate remains high. $70 \%$ of maternal deaths occur during delivery and the postpartum period.

\section{Objectives}

Perform a clinical audit of maternal deaths to identify causes to reduce the risk of maternal death, for care based on quality assurance.

\section{Methods}

This audit was performed through the use of a standard questionnaire on all deaths occurring in 2011; the questionnaire was sent to health administrators of the 48 health departments of Wilayas. Data analysis was performed on the software SSPRO.

\section{Results}

Out of 220 maternal deaths, 93\% occurred in hospital, $26 \%$ following an evacuation in an emergency. Some causes include hemorrhage 31.4\%; HTA / complication 12.7\%; cardiovascular 12.3\%; infections $6.4 \%$. The ages ranged from 19 to 55 years with an average of 32.9 years. The Deaths were most frequent at first pregnancy (39\%) and at fourth or later pregnancy (32\%). Outcomes for fetuses were live birth in $44.5 \%$, stillbirth in $33.6 \%$, and abortion in $2.7 \%$.

\section{Conclusion}

Access to essential obstetric care quality was limited: no hierarchy of levels of care, lack of organizational standards and functional at the hospital; evacuations late coupled with inefficient management of obstetric

Ministry of Health, Population and Hospital Reform, Algiers, Côte d'Ivoire emergencies. Weight of the high risk of cardiovascular disease.

\section{Disclosure of interest}

None declared.

Published: 20 June 2013

doi:10.1186/2047-2994-2-S1-P357

Cite this article as: Keddad: P357: A descriptive study of maternal deaths in Algeria in 2011. Antimicrobial Resistance and Infection Control 2013 2(Suppl 1):P357.
Submit your next manuscript to BioMed Central and take full advantage of:

- Convenient online submission

- Thorough peer review

- No space constraints or color figure charges

- Immediate publication on acceptance

- Inclusion in PubMed, CAS, Scopus and Google Scholar

- Research which is freely available for redistribution 